\title{
A HISTÓRIA SOCIAL DOS DIREITOS HUMANOS ENQUANTO HISTÓRIA DA ESPERANÇA
}

\author{
THE SOCIAL HISTORY OF HUMAN RIGHTS AS HISTORY OF HOPE
}

TRINDADE, José Damião de Lima. História social dos direitos humanos. 3. ed. São Paulo: Peirópolis, 2011.

Vinícius Reis Barbosa*

\begin{abstract}
RESUMO: Trata-se de resenha da obra de José Damião de Lima Trindade, intitulada "História social dos direitos humanos". Utilizando-se do materialismo histórico-dialético, o autor traça a história social do conjunto de idéias que se convencionou chamar de direitos humanos, demonstrando sua origem nitidamente classista, que remonta à revolução francesa. Identifica e demonstra ainda a historicidade das idéias que foram incorporadas ao ideário inicial ao longo do século XIX e XX através da luta de classes, bem como as atuais contribuições dos movimentos sociais e demais organizações da sociedade a partir da segunda metade do século XX.

Palavras-chave: direitos humanos. história social. marxismo.
\end{abstract}

ABSTRACT: This review is about the book of José Damião de Lima Trindade, entitled "Social history of human rights." Using the dialectical and historical materialism, the author traces the social history of the set of ideas that is usually called human rights, clearly demonstrating their class origin, dating back to the French Revolution. Identifies and further demonstrates the historicity of the ideas that were incorporated into the initial ideas throughout the nineteenth and twentieth century through the class struggle and the current contributions of social movements and other organizations of society from the second half of the twentieth century.

Keywords: human rights. social history. marxism.

O autor da obra em exame, ao fazer uma história social dos direitos humanos, resgata uma sequiência de fatos históricos muitas vezes esquecidos e cuja lembrança é de suma importância para se compreender a gênese de direitos que atualmente encontram-se reconhecidos em Declarações, Constituições e tratados internacionais, o que por si só facilita a compreensão que atualmente se deve ter de referidos direitos e a necessidade de lutar por sua efetivação material.

O autor (que é Procurador do Estado de São Paulo, onde atuou no Grupo de Trabalho de Direitos Humanos) longe de fazer uma historiografia clássica, marcada por matizes positivistas através da ênfase nos "grandes feitos" e nos "grandes nomes", emprega de maneira escorreita o método materialista histórico-dialético para explicar os movimentos da história que, a partir das contradições existentes nos modos de produção feudal e capitalista, foram responsáveis pelo surgimento dos direitos humanos. Destaque-se que somente desta forma é possível fazer uma história social dos direitos humanos, "com vigilante senso crítico - para não se apaixonar pelos fatos ou por seus protagonistas nem romper com eles antes de a narrativa completar-se." (TRINDADE, 2011, p. 16)

Partindo da análise das relações de produção existentes no modo de produção feudal e das contradições ínsitas a tais relações, o autor explica nos primeiros capítulos da obra a origem da burguesia e a construção do pensamento social que iria sustentar ideologicamente a Revolução Francesa, marco inicial dos direitos humanos. Os principais fatos históricos relativos à Revolução Francesa são percorridos, bem como os

\footnotetext{
* Mestrando do Programa de Pós-graduação em Direito da UNESP, campus de Franca/SP. Membro do Núcleo de Estudos de Direito Alternativo da UNESP/Franca (NEDA). Bolsista da Coordenação de Aperfeiçoamento de Pessoal de Nível Superior (CAPES). Advogado.
} 
documentos jurídicos que deles decorreram e os autores que foram utilizados para embasar teoricamente sua criação.

No correr da obra, o autor narra como esta burguesia revolucionária tornou-se conservadora, freando o ideário dos direitos humanos na igualdade formal de todos perante a lei, forma jurídica que satisfazia seus interesses de classe e que reduzia os direitos humanos a "uma ideologia, no sentido de discurso legitimador da nova dominação de classe." (TRINDADE, 2011, p. 131)

Não obstante tal situação, o desenvolvimento das forças produtivas e das relações de produção levou ao surgimento de uma nova classe social: o proletariado. E, quer queira quer não, a burguesia ensinou este proletariado a ser revolucionário, pois estava vivo o acúmulo prático e teórico das revoluções burguesas, onde o campesinato e a massa proletária tinham sido aliados dos burgueses na derrubada do antigo regime.

Assim é que durante o século XIX a "bandeira dos direitos humanos, aos poucos, na prática, mudava de mãos - e isso a faria também mudar de caráter" (TRINDADE, 2011, p. 115), já que o liberalismo econômico instaurado pela burguesia, ao invés de melhorar as condições de vida da imensa maioria da população rapidamente mostrou-se não ser vocacionado para tal, vez que expressão teórica do modo de produção capitalista, excludente por natureza.

As crises cíclicas do capitalismo na segunda metade do século XIX representam para o autor a primeira grande crise dos direitos humanos, momento em que houve um refluxo das poucas conquistas em matéria de direitos econômicos, sociais e culturais até então reconhecidos.

A segunda crise dos direitos humanos (ocorrida no período que antecedeu a Segunda Guerra Mundial) também é minuciosamente abordada na obra, sendo demonstrado que o ideário fascista, em especial na sua versão nazista, somente floresceu porque "semeava em solo fértil" (TRINDADE, 2011, p. 182), ou seja, ia de encontro com os interesses dos capitalistas da época, em especial o empresariado alemão interessado em retomar mercados externos perdidos com a derrota na Primeira Guerra Mundial e reavivar o mercado interno.

A configuração tomada pelos direitos humanos após a proclamação da Declaração de 1948 pela ONU e os pactos e tratados internacionais que se seguiram também são objeto de consideração do autor, ao afirmar que mais do que o direito posto, é a dinâmica das relações sociais que torna os direitos humanos eficazes ou os mantém inertes (TRINDADE, 2011, p. 197); não basta a positivação de direitos, mas sim a atuação concreta com vistas a efetivá-los.

Nesta mesma linha de pensamento analisa a estabilidade econômica dos anos 1940 a 1970, graças às políticas de intervenção estatal na economia e na efetivação de direitos humanos a partir do modelo de Estado de Bem-Estar Social implantado nos países de capitalismo desenvolvido e à custa da exploração neocolonial. Com argúcia, afirma o autor que a "parte pobre do mundo terminou contribuindo (novamente) para financiar a construção do bem-estar social na parte rica - uma espécie de transfusão de sangue às avessas, de organizamos debilitados para corpos robustos." (TRINDADE, 2011, p. 199), motivo pelo qual o Estado de Bem-Estar Social nos países periféricos pouco se efetivou.

$\mathrm{Na}$ sua caminhada para os dias atuais e os desafios que se impõem para os direitos humanos, o autor descreve a guinada ao neoliberalismo e se ideário de desregulamentação dos mercados e Estado mínimo, bem como as influências de tais concepções nos direitos humanos, finalizando com a idéia de que o futuro não está traçado, havendo possibilidade de mudança de direção (TRINDADE, 2011, p. 212), o 
que significa que não houve o tão apregoado "fim da história" e que o mundo encontrase aberto a novas possibilidades.

Em síntese, a obra de José Damião de Lima Trindade faz um resgate histórico imprescindível para os tempos atuais, onde a busca por efetivação dos direitos humanos é talvez a principal bandeira das forças democráticas, não sem oposição, velada ou escancarada, das forças conservadoras e reacionárias. Não por outro motivo Frei Betto, ao prefaciar a obra, a chamou de "uma história da esperança."

\section{REFERÊNCIAS}

TRINDADE, José Damião de Lima. História social dos direitos humanos. 3. ed. São Paulo: Peirópolis, 2011. 